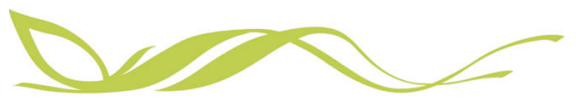

COMMUNICATIONS

ARTICLE

https://doi.org/10.1038/s43247-020-00054-x

OPEN

\title{
Ocean warming and acidification uncouple calcification from calcifier biomass which accelerates coral reef decline
}

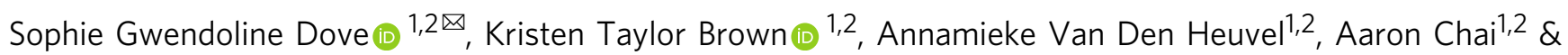
Ove Hoegh-Guldberg (1) 1,2,3

Global climate change will drive declines in coral reefs over coming decades. Yet, the relative role of temperature versus acidification, and the ability of resultant ecosystems to retain core services such as coastal protection, are less clear. Here, we investigate changes to the net chemical balances of calcium carbonate within complex experimental coral reefs over 18 months under conditions projected for 2100 if $\mathrm{CO}_{2}$ emissions continue unmitigated. We reveal a decoupling of calcifier biomass and calcification under the synergistic impact of warming and acidification, that combined with increased night-time dissolution, leads to an accelerated loss of carbonate frameworks. Climate change induced degradation will limit the ability of coral reefs to keep-up with sea level rise, possibly for thousands of years. We conclude that instead of simply transitioning to alternate states that are capable of buffering coastlines, reefs are at risk of drowning leading to critical losses in ecosystem functions.

\footnotetext{
${ }^{1}$ The University of Queensland, School of Biological Sciences, Coral Reef Ecosystems Laboratory, St. Lucia, QLD 4072, Australia. ${ }^{2}$ The University of Queensland, Australian Research Council Centre of Excellence for Coral Reef Studies, St. Lucia, QLD 4072, Australia. ${ }^{3}$ The University of Queensland, Global Change Institute, St. Lucia, QLD 4072, Australia. ${ }_{\text {email: sophie@uq.edu.au }}$
} 
S hallow water coral reefs provide living coastal barriers that protect people and infrastructure when the rate of accretion exceeds that of erosion ${ }^{1,2}$. In the short-term, major framework builders can rapidly rebuild three-dimensional (3D) structures after acute disturbances (e.g. storms) through high rates of reproduction, growth, and calcification ${ }^{3,4}$. In turn, the $3 \mathrm{D}$ structure reduces the motion of the water allowing for sediment infilling, such that over the long-term, high coral cover reefs stabilizing at an average porosity of $50 \%$ can vertically accrete at a maximal rate of $\sim 10 \mathrm{~mm} \mathrm{yr}^{-1}$ in response to sea-level rise ${ }^{5}$. Over the last 6000 years, modern coral reefs have been sustained under

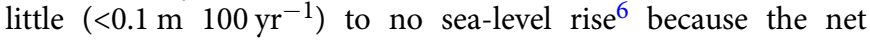
chemical balances of calcium carbonate $\left(\mathrm{CaCO}_{3}\right)$ have been in equilibrium with net physical export of $\mathrm{CaCO}_{3}$ from reefs ${ }^{7}$.

Recent and intensifying El Niño events have provided an acute and highly observable window into the future of coral reefs under the thermal impact of climate change. The accompanying underwater heatwaves demonstrate that there are latitude specific thermal thresholds whose exceedance initially drove observations of mass coral bleaching ${ }^{8}$; but, as events have become hotter for longer, large-scale coral mortality has become increasingly common ${ }^{9}$. The impacts of acidification on reefs, however, are not as visually evident and require microscopic examination ${ }^{10}$ or quantification via challenging chemical-physical methodologies ${ }^{11}$, and lie mostly in the future. Under increasing greenhouse gas (GHG) emissions, principally carbon dioxide $\left(\mathrm{CO}_{2}\right)$, acute thermal impacts will merge with chronic changes to seawater chemistry, increasing ocean temperature and decreasing aragonite saturation $\left(\Omega_{\mathrm{Ar}}\right)$ away from relatively stable states that have dominated for the last 420,000 years ${ }^{12}$. The extent of the future changes and associated risks is ultimately determined by human activities. However, if GHG emissions remain unchecked over the next few decades, we risk generating an atmospheric $\mathrm{pCO}_{2}$ anomaly that is 10 - to 20 -fold greater than that observed today ${ }^{13}$. The innumerable consequences will be mostly irreversible and imposed on humanity for hundreds to thousands of years ${ }^{13,14}$.

In order to study and understand this future and its implication for coral reef ecosystems, we built experimental reefs that closely resembled those of shallow reef slopes at Heron Island on the southern Great Barrier Reef ${ }^{15}$ (Fig. 1, Supplementary Figs. 1, 2). These replicated 'ecosystems' included an array of functionally diverse corals plus associated infauna growing on a foundation of previously deposited $\mathrm{CaCO}_{3}$ composed of dead coral fragments ('live rock') ${ }^{16} . \mathrm{CaCO}_{3}$ frameworks were allowed to be further built-up by the infilling of sediments created by a range of organisms including the calcifying alga, Halimeda ${ }^{17,18}$, and organisms such as foraminifera and Lithothamnion that are abundant in the sediments collected from the shallow reef slope of Heron Island ${ }^{19}$. The sediments and microbial populations therein were aerated by sea cucumbers ${ }^{20}$. Gardening damselfish nurtured turf algae ${ }^{21}$, while blennies consumed detritus, algae and cyanobacteria ${ }^{22}$. The typical age of water parcels in shallow seaward facing reef habitat is on the order of a few hours ${ }^{23}$. To accommodate these retention times and allow reef organisms to influence the water chemistry ${ }^{24}, \mathrm{CO}_{2}$ was only controlled in large $(8000 \mathrm{~L})$ upstream sumps with downstream tanks $(300 \mathrm{~L})$ containing experimental reefs turned-over once per hour.

The experimental system allowed for the direct measurement of the net chemical balances of $\mathrm{CaCO}_{3}$ (herein referred to as $\mathrm{NEC})^{25}$. NEC is distinct from census-based carbonate balances that tend to sum percent cover of calcifiers and bioeroders by converting each component to $\mathrm{CaCO}_{3}$ equivalents. Census-based conversions typically apply rates from the literature, as opposed to treatment or habitat-specific responses, and often focus on biological erosion rather than chemical ${ }^{26,27}$. Biological agents of erosion, however, retain $\mathrm{CaCO}_{3}$ within the reef infrastructure and operate as new foundation for reef construction ${ }^{28}$, whereas, the chemical loss of $\mathrm{CaCO}_{3}$ from reefs directly counters the production of $\mathrm{CaCO}_{3}$ by key reef calcifiers. $\mathrm{CaCO}_{3}$ structures lacking living tissue protection are especially vulnerable to increased chemical erosion under acidification, but there are also many documented cases of living reef-building corals exhibiting reductions in calcification rates as a result of exposure to acidification $^{10,28-30}$. Ecosystem components (e.g., macroalgae) may act as a buffer against acidification, with the suggestion that algal communities may benefit from increased seawater $\mathrm{pCO}_{2}$, take up $\mathrm{CO}_{2}$ and lessen the impact of ocean acidification on downstream organisms and structures ${ }^{24}$. The interactive effect, however, of matched warming to acidification on corals, algae and more importantly, complex reef communities over the longterm (>12 months) is rarely considered especially with regards to the RCP8.5 scenario ${ }^{31}$.

The present study involved the long-term exposure of experimental reefs to seawater environments expected by the end of the century (2100) (Fig. 1, Supplementary Figs. 1 and 2). Using this approach, we (1) mimic changes to future coral reef ecosystem dynamics; (2) identify potential "winners" capable of surviving end-of-century conditions; and (3) provide functional relationships between key reef processes, such as NEC rates, across a range of abiotic and biotic explanatory variables. The study thereby serves to provide an improved basis for understanding how diverse and complex reefs of the future may respond to a rapidly changing climate.

\section{Results and discussion}

Reef biota and NEC rates over time. Treatments were consistent with a seasonally dynamic end-of-century RCP8.5 scenario (Supplementary Figs. 3 and 4). The temperature difference between present day (PD) and RCP8.5 treatments was maintained at $\sim 3.5^{\circ} \mathrm{C}$, with respective means across the experimental period of $25.0^{\circ} \mathrm{C}$ and $28.5^{\circ} \mathrm{C}$ (Supplementary Fig. 3). Upstream $\mathrm{RCP} 8.5 \mathrm{pCO}_{2}$ sumps, which reflected the acidification status of the water mass fluxing onto our experimental reef, were maintained above PD values by 550 $\mu$ atm (Supplementary Fig. 3).

Temperature, $\mathrm{pCO}_{2}$, and time of day had an interactive effect on hourly NEC rates (Fig. 2, Supplementary Table 1). NEC rates were low and generally negative at night, increasing in the morning to a maximum and positive value around midday. The individual effect of RCP8.5 acidification had a positive effect on NEC by day, but a negative effect by night (Fig. 2). By contrast, reefs experiencing the combination of RCP8.5 temperature and acidification responded negatively at all time points relative to present day treatments (Fig. 2).

A strong seasonal trend in 24-h NEC was observed in PD treatments, with rates increasing over the austral summer and declining in winter (Fig. 3a). Experimental reefs experiencing only RCP8.5 warming began to show an increase in 24-h NEC for the final 7 months of the experiment, despite undergoing similar reductions in macro-calcifiers to those observed under RCP8.5 warming and acidification (Fig. 3a-d, Supplementary Fig. 5). Under the combined RCP8.5 effect, 24-h NEC rarely showed positive rates and existed in a state of net dissolution for the majority of the experiment (Fig. 3a).

Community composition varied by treatment with living hard coral cover maintained between 23 and $47 \%$ under PD conditions, but reduced over time to $<10 \%$ under treatments that involved RCP8.5 warming (Fig. 3b). Coral bleaching under the combination of RCP8.5 temperature and acidification occurred before the RCP8.5 temperature-only treatment (Fig. 1, Fig. 3c). However, greater sensitivity to bleaching amongst taxa was not found to be an indicator of coral thermal tolerance (e.g., 


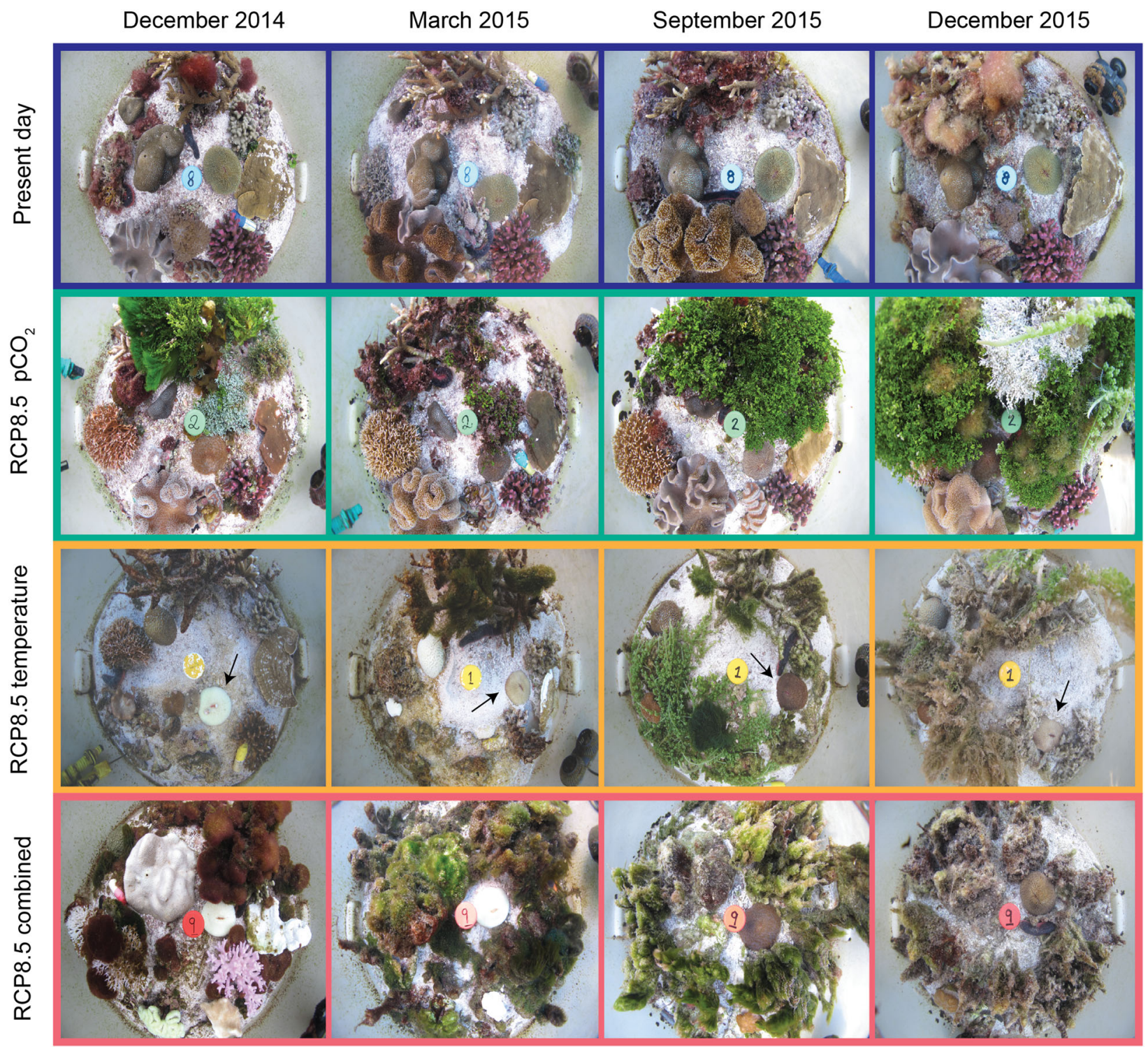

Fig. 1 Photographs of experimental coral reefs through time. Representative communities were assembled to replicate the natural communities of the Heron Island reef slope $(5 \mathrm{~m})$, southern Great Barrier Reef. Black arrows highlight bleaching, recovery and bleaching in Fungia.

Fungia was first to bleach but amongst survivors) (Fig. 1, Supplementary Figs. 1 and 2, Supplementary Table 2). The individual effect of RCP8.5 acidification tended to promote calcifying macroalgae in summer (Fig. 3d), most notably Halimeda (Fig. 1), which coincided with an increase in NEC (Fig. 3a, d). The winter Halimeda bloom observed under the combination of RCP8.5 warming and acidification did not, however, correlate with an increase in NEC (Fig. 3a, d). The abundance of macroalgae, turf algae and/or cyanobacteria was observed to increase significantly in any treatment that increased either temperature and/or acidification over PD values (Fig. $3 \mathrm{~d}-\mathrm{f}$ ). In RCP8.5 acidification treatments, average midday in-tank $\mathrm{pCO}_{2}$ were significantly less than upstream sump $\mathrm{pCO}_{2}$ values (Fig. 2).

Drivers of net ecosystem calcification (NEC). The best-fit model to explain daytime NEC rates incorporated temperature, in-tank $\mathrm{pCO}_{2}$, and cover of calcifying organisms (Fig. 4a, b, Supplementary Fig. 6, Supplementary Data 1,2). The significant interactive effects of temperature and $\mathrm{pCO}_{2}$ revealed that not only did the temperature optima for NEC decline as $\mathrm{pCO}_{2}$ increased, but the rate of $\mathrm{NEC}$ at optimal temperature declined (Fig. 4a,
Supplementary Fig. 6). For the same macro-calcifier cover, the difference in mean daytime NEC between PD conditions and RCP8.5 warming or RCP8.5 warming combined with acidification were $+0.23 \mathrm{gCaCO}_{3} \mathrm{~h}^{-1} \mathrm{~m}^{-2}$ and $-0.14 \mathrm{gCaCO}_{3} \mathrm{~h}^{-1} \mathrm{~m}^{-2}$ respectively (Fig. 4a, Table 1 ). These estimates include observed midday mitigation of $\mathrm{pCO}_{2}$ by reef biota (Fig. 2). For the same temperature and $\mathrm{pCO}_{2}$ levels, a reduction from 50 to $10 \%$ or from experimental maximum $60 \%$ to $<10 \%$ calcifier cover reduced daytime NEC by 0.29 and $0.88 \mathrm{gCaCO}_{3} \mathrm{~h}^{-1} \mathrm{~m}^{-2}$, respectively (Fig. 4b).

The best-fit model for night-time NEC rates incorporated temperature, in-tank $\Omega_{\mathrm{Ar}}$, and their interaction (Fig. 4c, Supplementary Fig. 6, Supplementary Data 1, 2). As temperature increased, increasing $\Omega_{\mathrm{Ar}}$ had a positive effect on calcification, while decreasing $\Omega_{\mathrm{Ar}}$ had a strong negative effect (Fig. 4c). The mean night-time NEC differences between PD conditions and RCP8.5 warming or RCP8.5 warming combined with acidification were $-0.06 \mathrm{gCaCO}_{3} \mathrm{~h}^{-1} \mathrm{~m}^{-2}$ and $-0.15 \mathrm{gCaCO}_{3} \mathrm{~h}^{-1} \mathrm{~m}^{-2}$, respectively (Fig. 4c; Table 1). RCP8.5 warming and acidification therefore had a negative interactive effect on $24 \mathrm{hr}$ NEC that could be offset by increasing the cover of calcifiers by $40 \%$ 


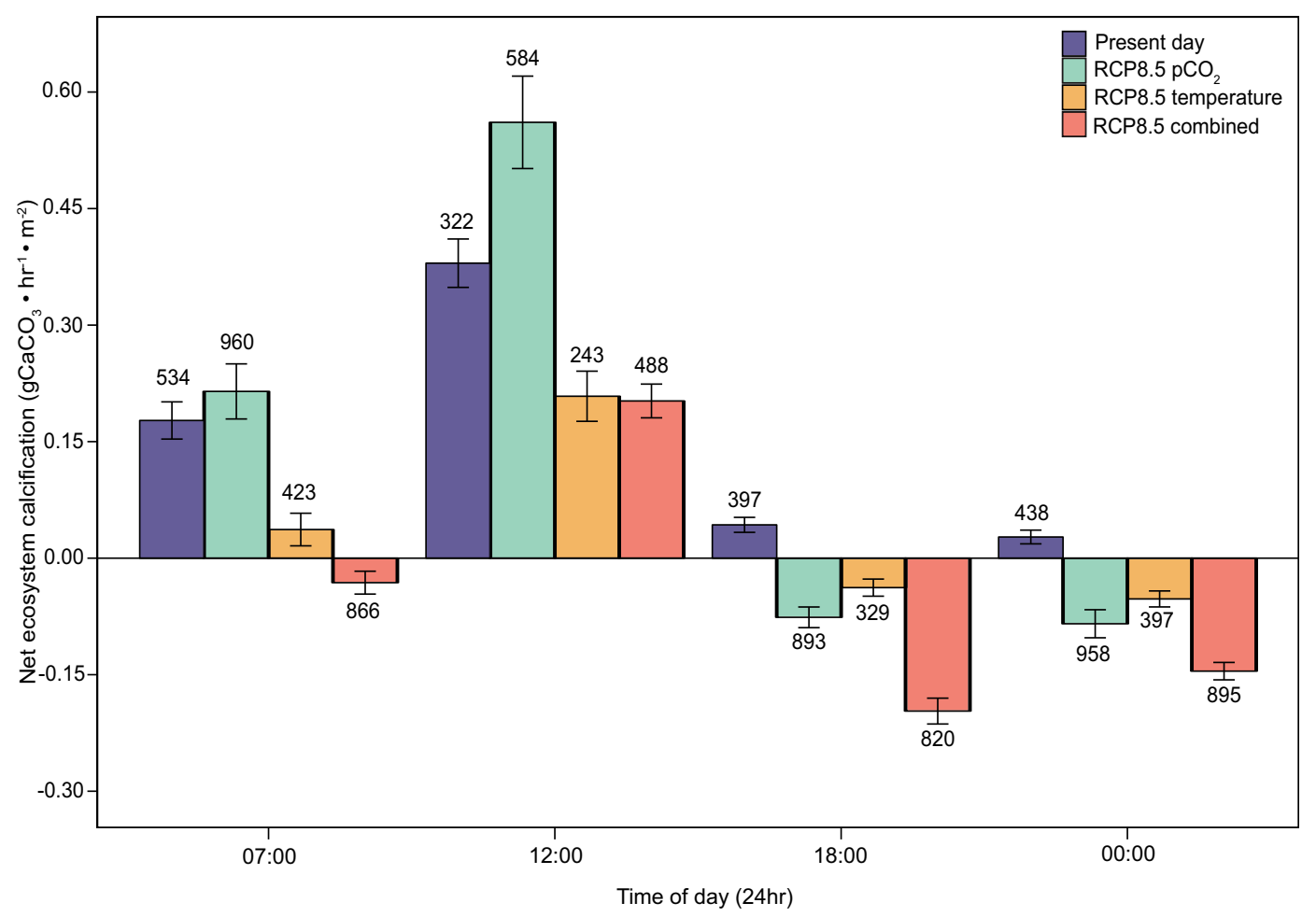

Fig. 2 Net ecosystem calcification rates by treatment and time of day. Effect of business-as-usual (RCP8.5) ocean acidification and/or warming on net ecosystem calcification rates (mean $\pm \mathrm{SE}$ ). Values above bars show mean in-tank $\mathrm{pCO}_{2}$ concentrations ( $\mu$ atm).

(equivalent to $0.29 \mathrm{gCaCO}_{3} \mathrm{~h}^{-1} \mathrm{~m}^{-2}$, Fig. $4 \mathrm{~b}$, Table 1). When abiotic effects are considered with biotic effects, RCP8.5 warming and RCP8.5 warming combined with acidification decreased the estimated maximal rate of reef accretion ${ }^{5}$ by $49 \pm 4 \%$ and $77 \pm$ $4 \%$, respectively (Table 1 ). Both estimates of decrease are likely conservative given that maximum calcifier cover in the present study was $60 \%$ compared to historic baseline estimates of $\sim 80 \%$ or more ${ }^{32}$.

Drivers of net photosynthesis and respiration. Daytime net photosynthesis $\left(\mathrm{O}_{2}\right.$ flux $)$ within our experimental reef systems was best described by a model that included the cover of photosynthesizing organisms, light and in-tank $\mathrm{pCO}_{2}$, together with a significant interaction between light and $\mathrm{pCO}_{2}$ (Supplementary Fig. 6, Supplementary Data 1,2). The inclusion of temperature did not, however, improve the model (Supplementary Data 2). Night-time respiration was best explained by the individual effect of temperature, with increased temperature significantly increasing respiration rates (Supplementary Fig. 7, Supplementary Data 1, 2).

Future reefs under RCP8.5. Our results demonstrate that measurements of coral community abundance (e.g., percent cover) do not account for the full impact of abiotic changes on reef carbonate sustainability. Temperature and acidification had direct effects on ecosystem calcification that remained when the impact associated with the abundance of key calcifying organisms was removed. The additional decrease in NEC, associated with the interaction of warming with acidification, was not driven by external bioeroders such as excavating parrotfishes ${ }^{27}$ that were absent from our experimental reefs. Currently, reefs that reach $\sim 10 \%$ coral cover are considered to transition to net-erosional reefs based principally on the biological activities of such eroders $^{26}$. The inclusion of these bioeroders within our experimental reefs, in combination with RCP8.5 warming and acidification, therefore has the potential to increase the accretion-erosion threshold to $\sim 50 \%$ coral cover. The literature ${ }^{12}$ and results presented here strongly suggest that the likelihood that hard corals, or even calcifying macroalgae, will flourish to this extent in the near future is small. In fact, few reefs today would meet this new target ${ }^{33,34}$. At $<10 \%$ coral cover, RCP8.5 reefs will not only decrease in height due to the loss of the 3D-structure provided by living hard coral, but the maximal vertical accretion of reef substrate will decrease by $\sim 7.7 \mathrm{mmyr}^{-1}$ (for a $50 \%$ porous reef) ${ }^{5}$ (Table 1). The same decrease associated with RCP8.5 temperature in the absence of acidification was only $\sim 4.9$ mmyr $^{-1}$ (Table 1). Our results scale with changes to the porosity of reef substrates. Reefs constructed with greater porosity (i.e., $\mathrm{CaCO}_{3}$ mostly distributed in branches of dead coral as opposed to infilled sediments) have greater rates of maximal vertical accretion (i.e., 20 $\mathrm{mmyr}^{-1}$ for a $75 \%$ porous reef ${ }^{35}$. Such reefs, however, have tended to form and subsist in sheltered locations ${ }^{35}$, and therefore, would be more prone to height reductions through physical destruction associated with exposure to greater wave energies in the future ${ }^{36}$.

Further and potentially catastrophic reductions in the upward extension of reefs are likely under RCP8.5 due to the increased susceptibility of previously established reef substrates to physical and chemical erosion ${ }^{28}$. Once infilled and consolidated, reefs may be subsequently hollowed-out and weakened, leading to reef structures that are increasingly vulnerable to physical erosion and collapse. At maximal average vertical accretion rates of $<2.3 \mathrm{mmyr}^{-1}$, future reefs will be unable to keep-up with conservative estimates $\left(5-15 \mathrm{mmyr}^{-1}\right)$ of sea-level rise ${ }^{37}$ over hundreds to thousands of years ${ }^{14}$. Similarly, but excluding the synergistic effects of warming and acidification, Perry et al..$^{38}$ conclude that reefs would have to maintain $60-70 \%$ coral cover to avoid submergence under RCP8.5. Again, adding our $40 \%$ cover equivalence for loss of NEC due to the synergistic impacts of warming and acidification, shifts Perry et al. ${ }^{38}$ submergence 

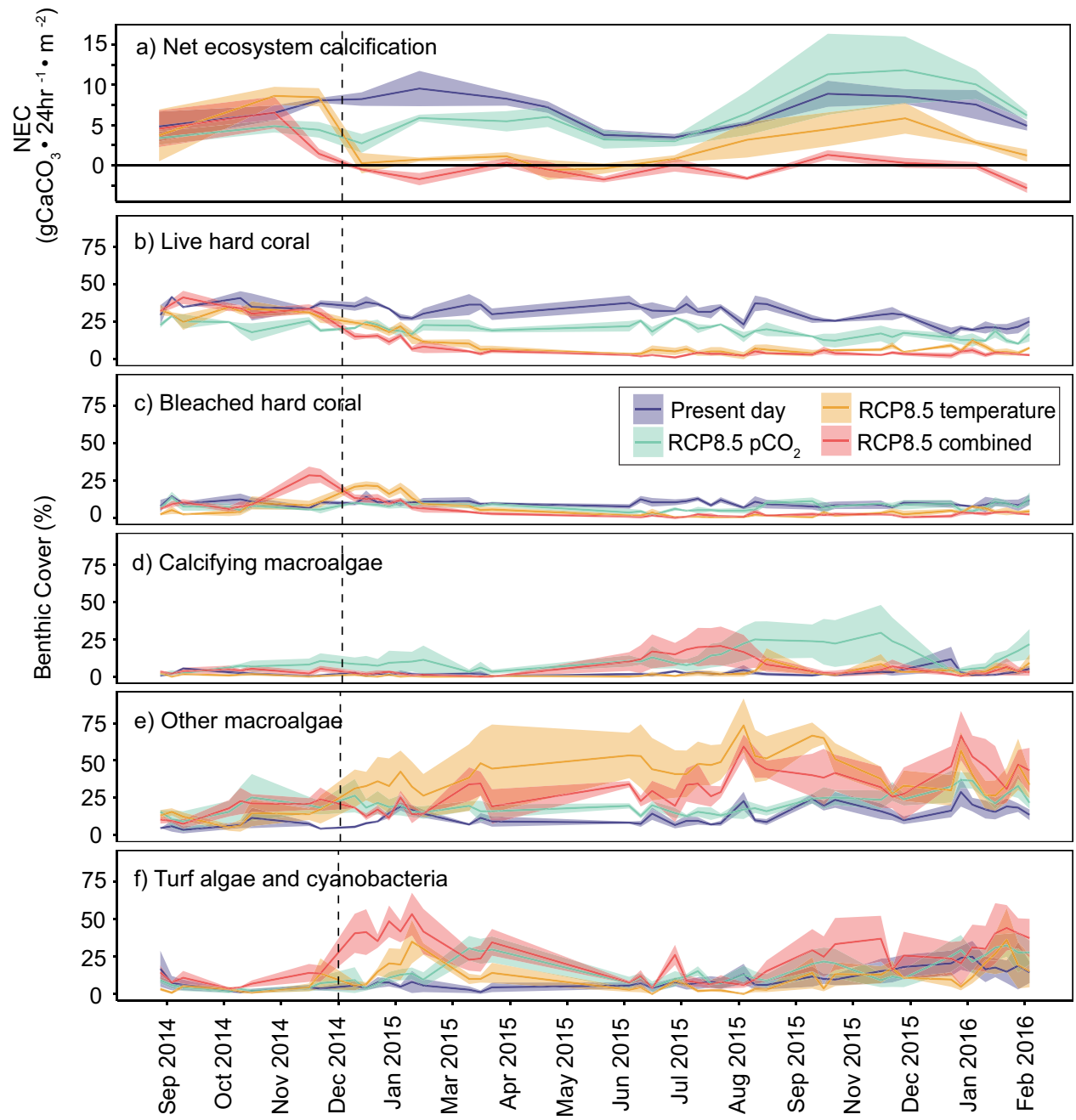

Fig. 3 Influence of ocean acidification and/or warming on net ecosystem calcification and benthic cover. a Integrated 24-h net ecosystem calcification rates indicate strong seasonal variation. Benthic cover was determined from weekly photographs across the 18-month experimental period for: $\mathbf{b}$ Live hard coral (Acropora, Montipora, Fungia, Lobophyllia, Porites, Platygyra, Seriatopora, and Stylophora), c Bleached hard coral, d Calcifying macroalgae (crustose coralline algae, Halimeda), e Other macroalgae (i.e., Lobophora, Caulerpa), and $\mathbf{f}$ turf algae and cyanobacteria. All lines are means \pm standard error. Dashed vertical line indicates the start of sampling period.

threshold to $\sim 100 \%$ cover. Our study demonstrates how studies that only include the effect of warming significantly underestimate the potential rate of reef decline. The impact of 3Dstructural loss on the reef's ability to dissipate wave-energy is expected to occur more immediately ${ }^{1}$. However, in the long-term, the increase in the depth of the reef substrate is expected to result in catastrophic land inundation and associated economic costs ${ }^{39}$. Land inundation and increased wave energy in back-reef areas is expected to increase sediment resuspension ${ }^{1}$, reducing light penetration and the depth at which reefs "drown"17. Increases in atmospheric $\mathrm{CO}_{2}$ under RCP8.5, therefore, have the potential to create a hiatus in reef formation, that is likely to prevail well beyond the stabilization of the planet's climate (Supplementary Fig. 8).

Not all coral genera responded equally to the experimental changes. Those that survived warming, in an average "recovery" year under RCP8.5, included Fungia, Lobophyllia, and the soft coral Sarcophyton (Supplementary Table 2). Fungia, singlepolyped solitary corals, and Lobophyllia do not contribute to the 3D structuring of reefs. Lobophyllia are fleshy corals that can dispense with colonial living as they age and tend not to interlink polyp corallites with $\mathrm{CaCO}_{3}{ }^{40,41}$. The results are consistent with current literature that identifies fleshy corals with reduced skeletal extension rates as more able to survive thermal stress than corals that invest less in tissue and more in skeletal extension ${ }^{42}$. Likewise, it is often noted that corals exposed to high $\mathrm{pCO}_{2}$ show regular skeletal extension rates, but calcify at reduced rates leading to more porous (i.e., less dense), weaker skeletons ${ }^{10,29,30}$. In exceptional cases, corals exposed to acidification can even forgo calcification and colonial living, as they convert to giant, fleshy single polyps ${ }^{43}$. None of these trade-offs are promising for coral reefs in the future, and all of them are likely to significantly inhibit the ability of reefs to accrete vertically in coastal regions that are expected to be exposed to higher wave energies with sea level rise ${ }^{44}$.

Night-time dissolution had a significant impact on the net calcification of the experimental reefs studied here. Reef sediments are sensitive to increases in organic matter deposited as organisms die because decomposition produces $\mathrm{CO}_{2}$ that can under saturate porewater $\Omega_{\mathrm{Ar}}{ }^{45,46}$. Acidification, by decreasing the $\Omega_{\mathrm{Ar}}$ of the overlying water mass, amplifies the impact of organic matter on sediment dissolution ${ }^{25}$. Likewise, by stimulating respiration, higher temperatures can increase the $\mathrm{pCO}_{2}$ concentration of reef waters percolating into the sediments ${ }^{46,47}$. In the experimental reefs described here, temperature had no effect on seawater net $\mathrm{O}_{2}$ flux by day, but had a highly significant 


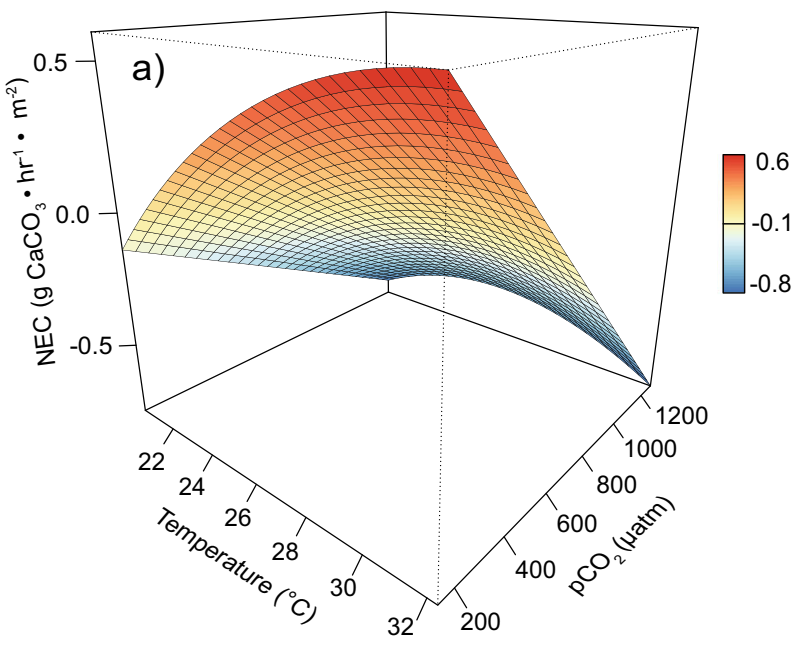

first half of the experiment ( $\sim 6$ months), but increased significantly towards the end of the experiment. The observed increase in NEC is likely due to: (1) biotic mitigation at mid-day resulting in an observed $50 \%$ decline in in-tank $\mathrm{pCO}_{2}$ for $\mathrm{RCP} 8.5$ acidification treatments; and, (2) increases in Halimeda biomass and calcification rates ${ }^{49}$ that were observable due to the long-term nature of the study. These phenomena more than offset the nocturnal dissolution of substrates observed under acidificationonly treatments. In the present study, the role that sediments play as contributors to the build-up of reefs and islands was only threatened when the acidification impact of an RCP8.5 scenario was matched by its thermal impact. Warming combined with acidification decoupled the relationship between calcifier cover and daytime net NEC, whilst accelerating rates of night-time dissolution.

Additional to observed night-time impacts, NEC declines relative to present day were observed under RCP8.5 acidification and warming during the day. These declines likely relate to previous observations of increased dissolution of dead coral substrates by endolithic algae and photosynthetic microbes ${ }^{50,51}$, as well as potential reduction in the calcification rates of surviving calcifiers that may direct energy acquired to biomass production and maintenance, as opposed to calcification ${ }^{42}$. A recent study has demonstrated that following a thermal stress event, the rate of dissolution of exposed $\mathrm{CaCO}_{3}$ framework can be significantly greater than the calcification rates of living coral ${ }^{52}$. Evidence for rapid structural loss following present day marine heatwaves emphasizes the potential for catastrophic loss of carbonate substrates under chronic future warming and acidification.

Some studies propose that corals will adapt to the new conditions improving the outcomes for reefs in ways that cannot be captured by short-term experiments. Against this notion, it is argued that the life cycles and generation times may be too long to facilitate this change ${ }^{53}$; or that any mechanisms of rapid adaptation is only sustainable under reduced emission scenar$\operatorname{ios}^{54}$. Others argue that this can be achieved via transcription changes occurring in response to epigenetic memory ${ }^{55}$. In such studies, bleaching susceptibility is often tied to mortality; however, in the present study and in recent observations of reefs impacted by significant underwater heatwave events, mortality was not correlated to bleaching susceptibility 9 . The focus on adaptations that prevent bleaching in the face of climate change obscure the potential costs on both primary (extension) and secondary (densification) calcification, even if they prove to facilitate coral survival. Our study argues for a decoupling of calcifier biomass and calcification rates under warming and acidification, and suggests that any adaption amongst key calcifiers would need to both increase survival potential and rates of calcification substantially above maximal rates observed in the past. The likelihood of such an outcome is poor, but reduces even further with observations regarding the ephemeral status of $\mathrm{CaCO}_{3}$ deposition by scleractinian corals, and their survival without fossil representation through 14 million year subsequent to the Permian extinction event ${ }^{56}$.

In summary, our results counter multiple modeling studies that argue that future acidification will play only a minor role in the future status of coral reefs ${ }^{57,58}$. The results of our experiments align with earlier models ${ }^{59}$ suggesting that acidification can seriously undermine the carbonate status of coral reef ecosystems, but do so only in combination with thermal stress. Our study suggests that reefs will erode more rapidly than under previous estimates $^{38}$, as they transition to alternate reef states under unmitigated climate change. Importantly, our calculations also include the potential mitigation of mid-day $\mathrm{pCO}_{2}$ by an enriched macroalgal community ${ }^{24}$, which is likely to dissipate with climate change, as the $3 \mathrm{D}$ structure of coral reefs and the retention of 
Table 1 Net ecosystem calcification $\left(\mathrm{NEC}_{1} \mathrm{gCaCO}_{3} \mathrm{~m}^{-2} \mathrm{~h}^{-1}\right)$ rates and percent change in vertical accretion relative to an optimal present day experimental reef.

\begin{tabular}{|c|c|c|c|c|c|c|c|}
\hline \multirow{2}{*}{$\begin{array}{l}\text { Responses: } \\
\text { Treatment }\end{array}$} & \multicolumn{4}{|c|}{ Abiotic predictors by time of day } & \multirow{2}{*}{$\begin{array}{l}\text { Biotic predictor } \\
\text { Relative to maximum } \\
\text { biomass }^{\star}\end{array}$} & \multicolumn{2}{|l|}{ Summed } \\
\hline & Morning & Noon & Night & $\begin{array}{l}24 \mathrm{~h} \\
\text { relative } \\
\text { to } \mathrm{PD}\end{array}$ & & $\begin{array}{l}24 \mathrm{~h} \text { Relative } \\
\text { to PD }\end{array}$ & $\begin{array}{l}\text { Change in max } \\
\text { vertical accretion\$ }\end{array}$ \\
\hline & \multicolumn{7}{|c|}{ NEC $\left( \pm\right.$ SE) Temperature $\left({ }^{\circ} \mathrm{C}\right), \mathrm{pCO}{ }_{2}(\mu a t m)$ or $\Omega_{\mathrm{ar}}$} \\
\hline Present day (PD) & $\begin{array}{l}0( \pm 0.1) \\
25.0,530\end{array}$ & $\begin{array}{l}0.2( \pm 0.1) \\
25.0,320\end{array}$ & $\begin{array}{l}-0.09( \pm 0.05) \\
25.0,3.5\end{array}$ & & & & \\
\hline $\begin{array}{l}\text { RCP8.5 temperature } \\
\text { only } \\
\text { RCP8.5 temperature } \\
\text { and acidification }\end{array}$ & $\begin{array}{l}0.25( \pm 0.1) \\
28.5,420 \\
-0.23( \pm 0.1) \\
28.5,870\end{array}$ & $\begin{array}{l}0.4( \pm 0.1) \\
28.5,250 \\
0.15( \pm 0.1) \\
28.5,490\end{array}$ & $\begin{array}{l}-0.15( \pm 0.05) \\
28.5,2.2 \\
-0.24( \pm 0.05) \\
28.5,2.2\end{array}$ & $\begin{array}{l}0.14 \\
( \pm 0.12) \\
-0.29 \\
( \pm 0.12)\end{array}$ & $\begin{array}{l}-0.88 \\
( \pm 0.05) \\
-0.88 \\
( \pm 0.05)\end{array}$ & $\begin{array}{l}-0.74 \\
( \pm 0.06) \\
-1.17 \\
( \pm 0.06)\end{array}$ & $\begin{array}{l}-49 \pm 4 \% \\
-77 \pm 4 \%\end{array}$ \\
\hline
\end{tabular}

NEC values obtained from Fig. 4 . ${ }^{*}$ NEC for 60 to $10 \%$ decrease in calcifier cover; ${ }^{\$}$ relative to maximal values $\left( \pm\right.$ SE) in $^{5}$.

water it creates collapses ${ }^{23}$. The conclusions strengthen the call for achieving the goals of the Paris Climate Agreement as a matter of global emergency.

\section{Methods}

Specimen collection and experimental design. The aim of the present study was to experimentally explore the impact of an average RCP8.5 future "recovery" year (i.e., non-El-Niño year) on the net ecosystem calcification (NEC) of experimental reefs reconstructed from a shallow $(5 \mathrm{~m})$ reef slope location at Heron Island on the southern Great Barrier Reef $\left(23^{\circ} 26^{\prime} \mathrm{S} 151^{\circ} 52^{\prime} \mathrm{E}\right)$. As an offshore reef, the input water into an experimental system on Heron Island has very low levels of coastal pollutants that can promote algal over coral growth ${ }^{60}$. The supply of oligotrophic water to reconstructed experimental mesocosms was important, as experimentally, we were limited to the provision of smaller motile herbivores such as gardening damsel fish (Pomacentrus wardii), lawn mower gobies (Salarias fasciatus), and an array of invertebrate detritivores and herbivores. The inclusion of sediments, live rock, crabs, snails and other infauna fed by flow through water from the reef, however insured the provision of food for the organisms, inclusive of corals present in the reconstructed experimental reefs. Representative concentration pathway 8.5 (RCP8.5) was selected because the experiment was conducted between June 2014 and March 2016; that is, prior to the Paris Climate Agreement. RCP8.5, however, represents our current rate of fossil fuel emissions despite global consensus for the adoption of policies that significantly reduce emissions ${ }^{61}$. Treatment conditions were gradually achieved over the 3-month period from June-August 2014.

To monitor the individual and combined impacts of an average non-El Niño "recovery" year under RCP8.5 temperature and acidification, we selected the relatively cool year of 2013 as our present-day (PD) baseline scenario. Temporal variability was introduced by following water temperature and $\mathrm{pCO}_{2}$ as measured at 2 hourly intervals at Harry's Bommie over 2013 (https://www.pmel.noaa.gov/ $\mathrm{co} 2 /$ story/Heron+Island). RCP8.5 scenarios were then off-set from this variable $\mathrm{PD}$ baseline by $+3.5^{\circ} \mathrm{C}$ and $+550 \mathrm{ppm}$. An orthogonal design of Temperature (PD, $\mathrm{RCP} 8.5) \times \mathrm{pCO}_{2}(\mathrm{PD}, \mathrm{RCP} 8.5)$ was implemented with $n=3$ downstream tanks $(300 \mathrm{~L})$, continuously fed at a turnover rate of $4.5 \mathrm{~L} \mathrm{~min}^{-1}$ by one of four upstream sumps. Sump, as opposed to tank $\mathrm{pCO}_{2}$, was controlled to allow organisms and their biology to influence in-tank $\mathrm{pCO}_{2}$. The flow-through rates $\left(>18 \mathrm{Lmin}^{-1}\right)$, size $(8000 \mathrm{~L})$ and the elimination of light from the sumps limited any containment effects and hence the potential for peudoreplication ${ }^{62}$. By contrast, light to tanks was mediated by filters (marine blue \#131, LEE Filters, Hampshire, UK) to replicate light conditions at $5 \mathrm{~m}$ depth; and, reduced tank turnover to mimic bodies of water that are typically retained for a few hours within shallow seaward facing reef slope environments ${ }^{23}$. Dove et al. ${ }^{15}$ provides further details regarding the mesocosm system and its control. Photosynthetically active radiation (Odyssey PAR sensor, Dataflow Systems Ltd, Christchurch, New Zealand) and temperature (HOBO Pendant UA-001-64, Onset, Bourne, USA) were measured continuously in each tank.

Each of the 12 experimental reefs (Fig. 1, Supplementary Figs. 1 and 2) contained sediments, algae (including Halimeda), live rock, soft coral (zoanthids, Sarcophyton, Xenia) and hard coral collected together with infauna from the reef slope of Harry's Bommie, Heron Island, Great Barrier Reef at a depth of $\sim 5 \mathrm{~m}$. Sea cucumbers ( $n=2$, per tank, Holothuria edulis), damselfish $(n=1$ per tank, Pomacentrus wardii), and blennies ( $n=3$ per tank, Salarias fasciatus) were collected from Heron Island reef flat. Sediments were immediately placed within each seawater filled tank to a depth of $4 \mathrm{~cm}$. Hard corals, except for Fungia, were placed on live rock to avoid direct contact with sediment. Soft corals and Halimeda were collected and incorporated into the tank together with the reef structure to which they were attached. Each tank was fitted with a powerful wavemaker (JVP202B, SunSun, Zhoushan, China) to minimize boundary layer effects that can have significant negative influence on the exchange of nutrients, $\mathrm{CO}_{2}$ and $\mathrm{O}_{2}{ }^{63}$. Tanks were established over a week in June 2014 (austral winter). At the end of the experiment, the non-coral invertebrate diversity was cataloged and found to include a broad range of organisms such as mollusks and crustaceans.

Physiological analyses. Hourly net ecosystem calcification (NEC), photosynthesis (NEP), and respiration (NER) were determined via tank incubations ( $1 \mathrm{~h}$ at 12:00, $2 \mathrm{~h}$ at 7:00, 18:00 and 0:00) and conducted every $\sim 5$ weeks over an 18-month experimental period. NEC was determined from changes in total alkalinity (AT). AT was determined via titration (T50 titrator, Mettler Toledo, Port Melbourne, Australia) using $0.1 \mathrm{M} \mathrm{HCl}$ and replicated $20 \mathrm{~g}$ seawater samples with a precision of $\pm 3 \mathrm{~mol} \mathrm{~kg}^{-1}$ or better using the Gran titration method ${ }^{15}$. Acid concentration was calibrated at the beginning of each titration session using the certified reference materials (CRM) from A.G. Dickson (Scripps Institute of Oceanography, San Diego, USA). pH electrodes (DGi101-SC, Mettler Toledo, Port Melbourne, Australia) were also calibrated at the beginning of each titration session using $\mathrm{pH}_{\mathrm{SW}}$ standard buffers of 4.00 and 7.00 (Hach, Loveland, USA), with an average precision from triplicate measurements of less than 0.010 units. $\mathrm{O}_{2}$ flux was determined with dissolved oxygen (DO) sensors (RINKO W, JFE Advantech, Hyōgo, Japan). Parameters of the carbonate system (in-tank incubation $\mathrm{pCO}_{2}$ and $\Omega_{\mathrm{Ar}}$ ) were calculated from temperature, salinity, $\mathrm{pH}$ (NBS) and AT using $\mathrm{CO}_{2} \mathrm{Calc}^{64}$ (Supplementary Fig. 4)

Determination of benthic community composition. Benthic cover was determined from weekly photographs (September 2014-February 2016), which were taken in the late afternoon with a high definition camera (PowerShot G12, Canon, Tokyo, Japan). Images were analyzed through automated image recognition based on machine learning using the online repository, CoralNet ${ }^{65}$. Targeted annotations ( $\geq 500$ points per category) were performed manually to establish color and texture patterns to be used as descriptors for benthic categories. Percent cover estimations were then achieved using Support Vector Machines, a machine-learning model, on 100 points per image in a $10 \times 10$ uniform grid. The following benthic categories were used, with the functional group displayed in brackets: Acropora (Live hard coral), Montipora (Live hard coral), Fungia (Live hard coral), Lobophyllia (Live hard coral), Porites cylindrica (Live hard coral), Platygyra (Live hard coral), Seriatopora (Live hard coral), Stylophora (Live hard coral), bleached Acropora (Bleached hard coral), bleached Montipora (Bleached hard coral), bleached Fungia (Bleached hard coral), bleached Lobophyllia (Bleached hard coral), bleached Porites cylindrica (Bleached hard coral), bleached Platygyra (Bleached hard coral), bleached Seriatopora (Bleached hard coral), bleached Stylophora (Bleached hard coral), Halimeda (calcifying macroalgae), crustose coralline algae (calcifying macroalgae), all other macroalgae (i.e., Caulerpa, Lobophora, Sargassum) and turf algae/cyanobacteria.

Statistical analyses. All statistical analyses were performed using R (version 3.5.1) ${ }^{66}$ and graphical representations were produced using the packages ggplot2 and $m g c v^{67,68}$.

The effects of temperature (PD, RCP8.5), $\mathrm{pCO}_{2}$ (PD, RCP8.5) and time of day $(0: 00,7: 00,12: 00,18: 00)$ on hourly NEC rates from December 2014 to February 2016 were analyzed using a linear mixed effect model using the function lme within the package 'nlme'. For all analyses, tank was included as a random effect. The interactive effect of treatment (PD temperature and $\mathrm{pCO}_{2} ; \mathrm{RCP} 8.5 \mathrm{pCO}_{2}$ only; RCP8.5 temperature only; RCP8.5 temperature and $\mathrm{pCO}_{2}$ ) and month (1-12) on 24-h NEC rates were determined using lme. The effect of treatment on the cover of live hard coral was assessed using lme. The effect of Halimeda on NEC rates under RCP8.5 $\mathrm{pCO}_{2}$ only was assessed using lme. The effect of treatment on macroalgal abundance was assessed using lme. The effect of treatment on cover of bleached coral at the beginning of the first austral summer (November 2014) was assessed using lme. Significant interactive effects were followed by pairwise comparison of estimate marginal means using the emmeans package with Tukey's adjusted $p$ values. Data were tested for homogeneity of variance and normality of distribution 
through graphical analyses of residual plots for all models. For all analyses, tanks $(n=3)$ were used as replicates.

The effect of treatment on benthic community composition was analyzed using permutational MANOVAs (PERMANOVA), with the fixed effects of temperature and $\mathrm{pCO}_{2}$ and random effect of tank using the adonis function from the 'vegan' package ${ }^{69}$. Resemblance matrices were obtained using Bray-Curtis dissimilarity and 9,999 permutations.

Generalized additive models (GAMs) were applied to data sets using the gam function from the package 'mgcv'67. GAMs were used to allow for any possible nonlinear effects of metrics on the response variable. Smooth terms were fit using thin plate regression splines (tp) and full tensor product interactions (te), with the number of knots restricted $(k=5)$ to produce conservative models and avoid overfitting. The simplest model within 2 AICc values of the model with the lowest AICc was selected as the best model (Supplementary Data 1,2).

To assess the relative contribution of environmental metrics in explaining NEC, photosynthesis (NEP) and respiration (NER), we fit all possible model combinations, using the following metrics as predictor variables: (i) temperature $\left({ }^{\circ} \mathrm{C}\right)$, (ii) light measured as photosynthetically active radiation (PAR in $\mu$ mol quanta $\mathrm{m}^{-2} \mathrm{~s}^{-1}$ ), (iii) $\mathrm{pCO}_{2}(\mu \mathrm{atm})$ or aragonite saturation state $\left(\Omega_{\mathrm{Ar}}\right)$ and (iv) percent cover of calcifying organisms (\%; sum of live hard coral and calcifying macroalgal cover, Supplementary Fig. 5), or photosynthesizing organisms (\%; sum of live hard coral, calcifying macroalgae, other macroalgae, and cyanobacteria, Supplementary Fig. 5). Tank was included as a random effect in all models. The model structure was developed using a stepwise procedure, where models were compared and selected using Akaike information criterion for small sample sizes (AICc) and AICc weight $\left(\omega_{\mathrm{i}}\right)$. Prior to analyses, all environmental metrics were tested for collinearity. To limit complexity, we fit models that included only up to three predictor variables and their interactions ${ }^{70}$.

Summed errors presented in Table 1 were generated via stochastic modeling applying "Norm.Inv (Rand()), mean, SD)" in Microsoft Excel for each component over 1000 iterations (years).

\section{Data availability}

All data are available in the manuscript or the supplementary materials. Original data can can be found on https://github.com/imkristenbrown/Uncoupling-calcification-fromcalcifier-biomass.

\section{Code availability}

All R-scripts generated for this study can be found on https://github.com/ imkristenbrown/Uncoupling-calcification-from-calcifier-biomass.

Received: 18 May 2020; Accepted: 5 November 2020;

Published online: 03 December 2020

\section{References}

1. Harris, D. L. et al. Coral reef structural complexity provides important coastal protection from waves under rising sea levels. Sci. Adv. 4, eaao4350 (2018).

2. Andersson, A. J. \& Gledhill, D. Ocean acidification and coral reefs: effects on breakdown, dissolution, and net ecosystem calcification. Ann. Rev. Mar. Sci. 5, 321-348 (2013).

3. Ortiz, J.-C. et al. Impaired recovery of the Great Barrier Reef under cumulative stress. Sci. Adv. 4, eaar6127 (2018)

4. Highsmith, R. C., Riggs, A. C. \& Antonio, C. M. D. Survival of hurricanegenerated coral fragments and a disturbance model of reef calcification / growth rates. Oecologia 46, 322-329 (1980).

5. Buddemeier, R. W. \& Smith, S. V. Coral reef growth in an era of rapidly rising sea level: predictions and suggestions for long-term research. Coral Reefs 7 , 51-56 (1988)

6. Hallmann, N. et al. Ice volume and climate changes from a 6000 year sea-level record in French Polynesia. Nat. Commun. 9, 285 (2018).

7. Eyre, B. D., Andersson, A. J. \& Cyronak, T. Benthic coral reef calcium carbonate dissolution in an acidifying ocean. Nat. Clim. Change 4, 969-976 (2014).

8. Hoegh-Guldberg, O. Climate change, coral bleaching and the future of the world's coral reefs. Mar. Freshw. Res. 50, 839-866 (1999).

9. Hughes, T. P. et al. Global warming transforms coral reef assemblages. Nature 556, 492-496 (2018)

10. Venn, A. A. et al. Impact of seawater acidification on $\mathrm{pH}$ at the tissue-skeleton interface and calcification in reef corals. Proc. Natl Acad. Sci. USA 110 1634-1639 (2013)

11. Chisholm, J. R. M. \& Gattuso, J.-P. Validation of the alkalinity anomaly technique for investigating calcification of photosynthesis in coral reef communities. Limnol. Oceanogr. 36, 1232-1239 (1991).

12. Hoegh-Guldberg, O. et al. Coral reefs under rapid climate change and ocean acidification. Science 318, 1737-1742 (2007).
13. Zickfeld, K. \& Herrington, T. The time lag between a carbon dioxide emission and maximum warming increases with the size of the emission. Environ. Res. Lett. 10, 031001 (2015).

14. Zickfeld, K. et al. Long-term climate change commitment and reversibility: an EMIC intercomparison. J. Clim. 26, 5782-5809 (2013).

15. Dove, S. G. et al. Future reef decalcification under a business-as-usual $\mathrm{CO}_{2}$ emission scenario. Proc. Natl Acad. Sci. USA 110, 15342-15347 (2013).

16. Hallock, P. Coral reefs, carbonate sediments, nutrients, and global change. In The history and sedimentology of ancient reef systems (ed. Stanley, G. D.) 387-427 (Springer, Boston, MA, 2001), https://doi.org/10.1007/978-1-46151219-6_11.

17. Hallock, P. \& Schlager, W. Nutrient excess and the demise of coral reefs and carbonate platforms. Palaios 1, 389-398 (1986).

18. Drew, E. A. Halimeda biomass, growth rates and sediment generation on reefs in the central great barrier reef province. Coral Reefs J. Int. Soc. Reef Stud. 2, 101-110 (1983).

19. Maxwell, W. G. H., Jell, J. S. \& McKellar, R. G. Differentiation of Carbonate Sediments in the Heron Island Reef. SEPM J. Sediment. Res. 34, 294-308 (1964).

20. Uthicke, S. Sediment bioturbation and impact of feeding activity of Holothuria (Halodeima) atra and Stichopus chloronotus, two sediment feeding holothurians, at Lizard Island, Great Barrier Reef. Bull. Mar. Sci. 64, 129-141 (1999).

21. Bender, D., Champ, C. M., Kline, D., Diaz-Pulido, G. \& Dove, S. Effects of "reduced" and "business-as-usual" $\mathrm{CO}_{2}$ emission scenarios on the algal territories of the damselfish Pomacentrus wardi (Pomacentridae). PLoS ONE 10, e0131442 (2015)

22. Wilson, S. K. Growth, mortality and turnover rates of a small detritivorous fish. Mar. Ecol. Prog. Ser. 284, 253-259 (2004).

23. Lowe, R. J. \& Falter, J. L. Oceanic forcing of coral reefs. Ann. Rev. Mar. Sci. 7, 43-66 (2015).

24. Anthony, K. R. N., A. Kleypas, J. \& Gattuso, J. P. Coral reefs modify their seawater carbon chemistry - implications for impacts of ocean acidification. Glob. Chang. Biol 17, 3655-3666 (2011).

25. Eyre, B. D. et al. Coral reefs will transition to net dissolving before end of century. Science. 359, 908-911 (2018).

26. Perry, C. T. et al. Caribbean-wide decline in carbonate production threatens coral reef growth. Nat. Commun. 4, 1402 (2013).

27. Perry, C. T. et al. Changing dynamics of Caribbean reef carbonate budgets: emergence of reef bioeroders as critical controls on present and future reef growth potential. Proc. R. Soc. B Biol. Sci. 281, 1796 (2014)

28. Schönberg, C., Fang, J., Carreiro-Silva, M., Tribollet, A. \& Wisshak, M. Bioerosion: the other ocean acidification problem. ICES J. Mar. Sci. 74, 895-925 (2017).

29. Fantazzini, P. et al. Gains and losses of coral skeletal porosity changes with ocean acidification acclimation. Nat. Commun. 6, 7785 (2015)

30. Mollica, N. R. et al. Ocean acidification affects coral growth by reducing skeletal density. Proc. Natl Acad. Sci. USA 115, 1754-1759 (2018).

31. Kroeker, K. J. et al. Impacts of ocean acidification on marine organisms: quantifying sensitivities and interaction with warming. Glob. Chang. Biol 19 , 1884-1896 (2013)

32. Eddy, T. D., Cheung, W. W. L. \& Bruno, J. F. Historical baselines of coral cover on tropical reefs as estimated by expert opinion. PeerJ 6, e4308 (2018).

33. Selig, E. \& Bruno, J. A global analysis of the effectiveness of marine protected areas in preventing coral Loss. PLoS ONE 5, e9278 (2010).

34. De'ath, G., Fabricius, K. E., Sweatman, H. \& Puotinen, M. The 27-year decline of coral cover on the Great Barrier Reef and its causes. Proc. Natl Acad. Sci. USA 109, 17995-17999 (2012).

35. Roff, G., Zhao, J. \& Pandolfi, J. M. Rapid accretion of inshore reef slopes from the central Great Barrier Reef during the late Holocene. Geology 43, 343-346 (2015).

36. Stanley, G. D. Introduction to Reef Ecosystems and Their Evolution. In The history and sedimentology of ancient reef systems (ed. Stanley, G.) 1-39 (Springer, Boston, MA, 2001), https://doi.org/10.1007/978-1-4615-1219-6_1.

37. Church, J. et al. Sea Level Change. In Climate Change 2013: The Physical Science Basis. Contribution of Working Group I to the Fifth Assessment Report of the Intergovernmental Panel on Climate Change (eds. Stocker, T. et al.) 1137-1216 (Cambridge University Press, 2013).

38. Perry, C. T. et al. Loss of coral reef growth capacity to track future increases in sea level. Nature 558, 396-400 (2018).

39. Beck, M. W. et al. The global flood protection savings provided by coral reefs Nat. Commun. 9, 2186 (2018)

40. Veron, J. E. N. Corals of the World. (Australian Institute of Marine Science, 2000).

41. Brickner, I., Oren, U., Frank, U. \& Loya, Y. Energy integration between the solitary polyps of the clonal coral Lobophyllia corymbosa. J. Exp. Biol. 209, 1690-1695 (2006) 
42. Anthony, K. R. N., Connolly, S. R. \& Willis, B. L. Comparative analysis of energy allocation to tissue and skeletal growth in corals. Limnol. Oceanogr. 47, 1417-1429 (2002).

43. Fine, M. \& Tchernov, D. Scleractinian coral species survive and recover from decalcification. Science. 315, 1811 (2007).

44. Siegle, E. \& Costa, M. B. Nearshore wave power increase on reef-shaped coasts due to sea-level rise. Earth's Future 5, 1054-1065 (2017).

45. Andersson, A. J. A fundamental paradigm for coral reef carbonate sediment dissolution. Front. Mar. Sci. 2, 52 (2015)

46. Comeau, S., Lantz, C. A., Edmunds, P. J. \& Carpenter, R. C. Framework of barrier reefs threatened by ocean acidification. Glob. Chang. Biol. 22, 1225-1234 (2016).

47. Lantz, C. A., Schulz, K. G., Stoltenberg, L. \& Eyre, B. D. The short-term combined effects of temperature and organic matter enrichment on permeable coral reef carbonate sediment metabolism and dissolution. Biogeosciences 14, 5377-5391 (2017).

48. Shamberger, K. E. F., Lentz, S. J. \& Cohen, A. L. Low and variable ecosystem calcification in a coral reef lagoon under natural acidification. Limnol. Oceanogr. 63, 714-730 (2018).

49. Vogel, N., Meyer, F. W., Wild, C. \& Uthicke, S. Decreased light availability can amplify negative impacts of ocean acidification on calcifying coral reef organisms. Mar. Ecol. Prog. Ser. 521, 49-61 (2015).

50. Reyes-Nivia, C., Diaz-Pulido, G., Kline, D., Guldberg, O. H. \& Dove, S. Ocean acidification and warming scenarios increase microbioerosion of coral skeletons. Glob. Chang. Biol. 19, 1919-1929 (2013).

51. Kline, D. I. et al. Living coral tissue slows skeletal dissolution related to ocean acidification. Nat. Ecol. Evol. 3, 1438-1444 (2019).

52. Leggat, W. P. et al. Rapid coral decay is associated with marine heatwave mortality events on reefs. Curr. Biol. 29, 2723-2730.e4 (2019).

53. Császár, N. B. M., Ralph, P. J., Frankham, R., Berkelmans, R. \& van Oppen, M. J. H. Estimating the potential for adaptation of corals to climate warming. PLOS ONE 5, e9751 (2010).

54. Matz, M., Treml, E., Aglyamova, G. \& Bay, L. K. Potential and limits for rapid genetic adaptation to warming in a Great Barrier Reef coral. PLoS Genet. 14, e1007220 (2018).

55. Torda, G. et al. Rapid adaptive responses to climate change in corals. Nat. Clim. Change 7, 627-636 (2017)

56. Stanley, J. \& Fautin, D. G. The origins of modern corals. Science. 291, 1913-1914 (2001).

57. Couce, E., Ridgwell, A. \& Hendy, E. J. Future habitat suitability for coral reef ecosystems under global warming and ocean acidification. Glob. Change Biol. 19, 3592-3606 (2013).

58. Courtney, T. A. et al. Environmental controls on modern scleractinian coral and reef-scale calcification. Sci. Adv. 3, e1701356 (2017).

59. Kleypas, J. et al. Geochemical consequences of increased atmospheric carbon dioxide on coral reefs. Science 284, 118-120 (1999).

60. Brown, K. T. et al. The dynamics of coral-algal interactions in space and time on the southern Great Barrier Reef. Front. Mar. Sci 5, 181 (2018).

61. Rogelj, J. et al. Paris Agreement climate proposals need a boost to keep warming well below $2^{\circ} \mathrm{C}$. Nature 534, 631-639 (2016).

62. Cornwall, C. E. \& Hurd, C. L. Experimental design in ocean acidification research: problems and solutions. ICES J. Mar. Sci. J. du Cons 73, 572-581 (2016).

63. Chan, N. C. S., Wangpraseurt, D., Kühl, M. \& Connolly, S. R. Flow and coral morphology control coral surface $\mathrm{pH}$ : implications for the effects of ocean acidification. Front. Mar. Sci. 3, 10 (2016).

64. Robbins, L. L., Hansen, M. E., Kleypas, J. A. \& Meylan, S. C. CO2calc: A userfriendly seawater carbon calculator for Windows, Mac OS X, and iOS (iPhone). U.S. Geological Survey Open-File Report 1280 (2010).

65. Beijbom, O., Edmunds, P. J., Kline, D. I., Mitchell, B. G. \& Kriegman, D. Automated annotation of coral reef survey images. In 2012 IEEE Conference on Computer Vision and Pattern Recognition 1170-1177 (IEEE, 2012), https:// doi.org/10.1109/CVPR.2012.6247798.

66. R Core Team. $R$ : A language and environment for statistical computing. $R$ Foundation for Statistical Computing (2014). http://www.R-project.org/.

67. Wood, S. Generalized additive models: an introduction with R. (Chapman and Hall/CRC, 2017). https://doi.org/10.1201/9781315370279.

68. Wickham, H. ggplot2: elegant graphics for data analysis. (Springer-Verlag New York, 2016), https://doi.org/10.1080/15366367.2019.1565254.

69. Oksanen, J. et al. The vegan package. Community Ecol. Packag 10, 719 (2007)

70. Zinke, J. et al. Gradients of disturbance and environmental conditions shape coral community structure for south-eastern Indian Ocean reefs. Divers. Distrib. 24, 605-620 (2018).

\section{Acknowledgements}

We thank Mark Snowball, Giovanni Bernal-Carrillo and the members of the Coral Reef Ecosystems laboratory at the University of Queensland for assistance with the maintenance of the experimental system. Draft reviews by Amatzia Genin and Veronica Radice improved the manuscript. The experiment was funded by the Australian Research Council (ARC) and by the National Oceanic and Atmospheric Administration (NOAA) via ARC Centre of Excellence for Coral Reef Studies CE140100020 (S.G.D. and O.H-G.) and ARC Linkage LP110200874 (O.H-G. and S.G.D.).

\section{Author contributions}

S.G.D. and O.H.-G. initiated the study. S.G.D., A.H. and A.C. collected and collated the data. S.G.D. and K.T.B. analyzed the data. S.G.D., A.H. and A.C. optimized the experimental system. S.G.D., K.T.B. and O.H.-G. contributed to the writing of the paper.

\section{Competing interests}

The authors declare no competing interests.

\section{Additional information}

Supplementary information is available for this paper at https://doi.org/10.1038/s43247020-00054-x.

Correspondence and requests for materials should be addressed to S.G.D.

Peer review information Primary handling editors: Heike Langenberg.

Reprints and permission information is available at http://www.nature.com/reprints

Publisher's note Springer Nature remains neutral with regard to jurisdictional claims in published maps and institutional affiliations.

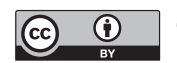

Open Access This article is licensed under a Creative Commons Attribution 4.0 International License, which permits use, sharing, adaptation, distribution and reproduction in any medium or format, as long as you give appropriate credit to the original author(s) and the source, provide a link to the Creative Commons license, and indicate if changes were made. The images or other third party material in this article are included in the article's Creative Commons license, unless indicated otherwise in a credit line to the material. If material is not included in the article's Creative Commons license and your intended use is not permitted by statutory regulation or exceeds the permitted use, you will need to obtain permission directly from the copyright holder. To view a copy of this license, visit http://creativecommons.org/ licenses/by/4.0/.

(c) The Author(s) 2020 